\title{
Isolation of Francisella tularensis from Skin Ulcer after a Tick Bite, Austria, 2020
}

\author{
Mateusz Markowicz ${ }^{1, *}$, Anna-Margarita Schötta ${ }^{1}$ (D), Freya Penatzer ${ }^{2}$, Christoph Matscheko ${ }^{2}$, Gerold Stanek $^{1}$, \\ Hannes Stockinger ${ }^{1}$ (D) and Josef Riedler ${ }^{2}$
}

1 Center for Pathophysiology, Infectiology and Immunology, Institute for Hygiene and Applied Immunology, Medical University of Vienna, Kinderspitalgasse 15, A-1090 Vienna, Austria; anna-margarita.schoetta@meduniwien.ac.at (A.-M.S.); gerold.stanek@meduniwien.ac.at (G.S.); hannes.stockinger@meduniwien.ac.at (H.S.)

2 Kardinal Schwarzenberg Klinikum, Kardinal Schwarzenbergplatz 1, A-5620 Schwarzach, Austria; freya.penatzer@gmx.at (F.P.); christoph.matscheko@ks-klinikum.at (C.M.); josef.riedler@ks-klinikum.at (J.R.)

* Correspondence: mateusz.markowicz@meduniwien.ac.at; Tel.: +43-1-40160-33023

check for

updates

Citation: Markowicz, M.; Schötta, A.-M.; Penatzer, F.; Matscheko, C.; Stanek, G.; Stockinger, H.; Riedler, J. Isolation of Francisella tularensis from Skin Ulcer after a Tick Bite, Austria, 2020. Microorganisms 2021, 9, 1407. https://doi.org/10.3390/

microorganisms 9071407

Academic Editor: Marina Santic

Received: 10 June 2021

Accepted: 25 June 2021

Published: 29 June 2021

Publisher's Note: MDPI stays neutral with regard to jurisdictional claims in published maps and institutional affiliations.

Copyright: (C) 2021 by the authors. Licensee MDPI, Basel, Switzerland. This article is an open access article distributed under the terms and conditions of the Creative Commons Attribution (CC BY) license (https:/ / creativecommons.org/licenses/by/ $4.0 /)$.

\begin{abstract}
Ulceroglandular tularemia is caused by the transmission of Francisella tularensis by arthropods to a human host. We report a case of tick-borne tularemia in Austria which was followed by an abscess formation in a lymph node, making drainage necessary. F. tularensis subsp. holarctica was identified by PCR and multilocus sequence typing.
\end{abstract}

Keywords: tularemia; Francisella tularensis; tick; multi locus sequence typing

Depending on the transmission route of Francisella tularensis, tularemia can present as a local infection or a systemic disease [1]. Transmission of the pathogen takes place by contact with infected animals, by bites of arthropods or through contaminated water and soil. Hares and wild rabbits are the main reservoirs of the pathogen in Austria [2]. According to the Austrian Agency for Food and Health Safety, an accumulation of fatal cases in hares was observed in the district of Salzburg in 2018 [3]. We report a case of ulceroglandular tularemia after a tick bite which occurred in Austria in the same district. Knowledge about local epidemiology of tularemia is crucial for correct diagnosis and treatment, given the wide range of various pathogens which can be transmitted by ticks to humans.

\section{The Patient}

At the end of June 2020, a 10-year-old boy from the district of Salzburg experienced a tick bite on his neck. The boy was playing near a rabbit hatch, but he had no contact with the animals. On the same day when the tick was removed, he was subfebrile, and the site of the tick bite appeared swollen and red. The skin lesion suggested a local infection, and treatment with amoxicillin for 10 days was started. However, a few days later, ulceration on the site of the tick bite and submandibular lymphadenopathy developed (Figure 1).

Physical examination revealed small, circumscribed, raised redness with a central crust on day 8 after the tick bite. Purulent discharge was sent for routine microbiological testing and methicillin-resistant Staphylococcus epidermidis was cultured. Sonography showed an enlarged left lymph node at the caudal parotid pole with no signs of abscess and several reactive lymph nodes in the left vascular nerve sheath. The treatment was changed to topical fusidic acid and alcohol-based wound cleaning. Two and a half weeks after the tick bite, the patient developed abscessing lymphadenopathy, and the antibiotic treatment was changed to ampicillin/sulbactam. Abscess drainage became necessary, but no growth of pathogens was observed in a conventional culture. At this time point, the laboratory diagnostic tests revealed a moderately elevated leukocyte count $(11.2 / \mathrm{nL})$, a normal red cell and platelet count, a normal C-reactive protein and unremarkable liver function parameters. Serologic testing for tick-borne infections was carried out and elevated antibodies to 
F. tularensis were found by an agglutination assay (CCPro, Oberdorla, Germany) and ELISA (Virion/Serion, Würzburg, Germany) (Table 1).

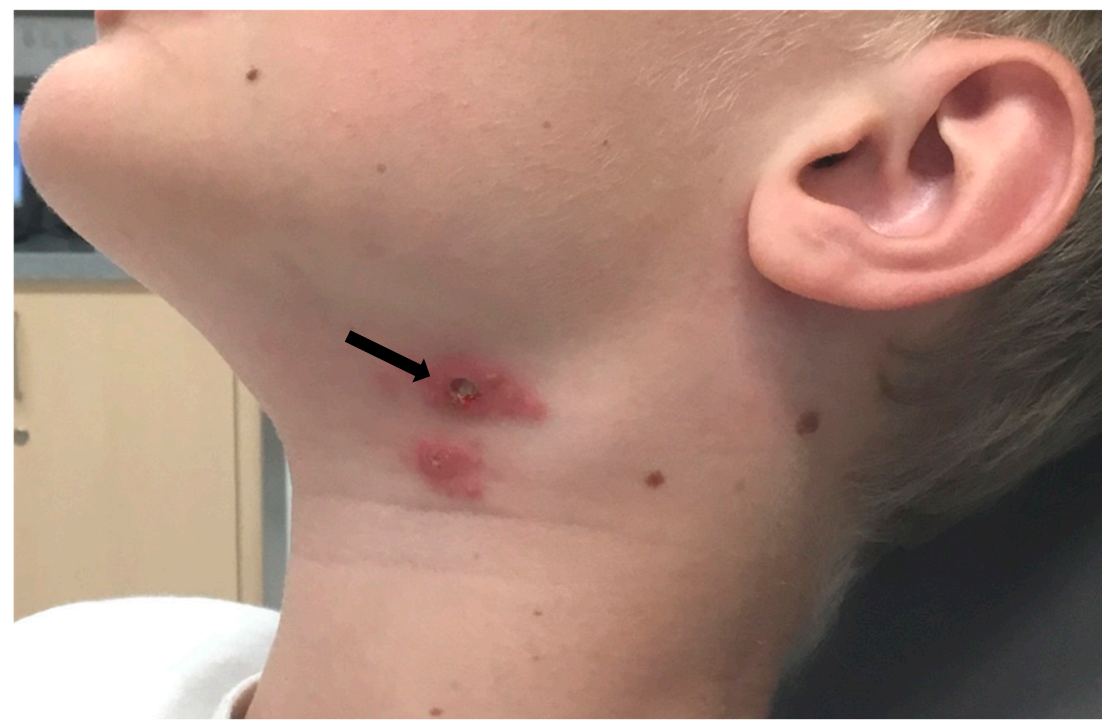

Figure 1. Clinical presentation of ulceroglandular tularemia after tick bite. The ulceration on the site of the tick bite is indicated by an arrow. Lymphadenopathy visible right from the inoculation site.

Table 1. Serologic test results of the patient with ulceroglandular tularaemia after the tick bite at the end of June 2020.

\begin{tabular}{|c|c|c|c|c|}
\hline & 21 July 2020 & 5 August 2020 & 10 September 2020 & 8 April 2021 \\
\hline F. tularensis (agglutination assay, positive $\geq 1: 80$ ) & $1: 160$ & $1: 320$ & $1: 320$ & $1: 160$ \\
\hline F. tularensis IgG (EIA, positive $\geq 1: 80)$ & 117 & 194 & $>300 \mathrm{U} / \mathrm{ml}$ & 213 \\
\hline F. tularensis IgM (EIA, positive $\geq 1: 80$ ) & 176 & 214 & $>400 \mathrm{U} / \mathrm{ml}$ & 171 \\
\hline$R$. conorii IgG (IIFT, positive $\geq \overline{1}: 64$ ) & $<1: 64$ & $<1: 64$ & np. & np. \\
\hline R. conorii IgM (IIFT, positive $\geq 1: 64$ ) & $<1: 64$ & $<1: 64$ & np. & np. \\
\hline B. henselae IgG (IIFT, positive $\geq 1: 320$ ) & 1:1000 & 1:1000 & np. & np. \\
\hline Borrelia burgdorferi sl IgG (EIA, positive $\geq 22 \mathrm{RE} / \mathrm{mL}$ ) & 4 & 4 & np. & np. \\
\hline Borrelia burgdorferi sl IgM (EIA, positive $\geq 22 \mathrm{RE} / \mathrm{mL}$ ) & 15 & 39 & np. & np. \\
\hline
\end{tabular}

np.: not performed.

Rickettsia spp. infection was ruled out by an immunofluorescence assay (Focus Diagnostics, Cypress, CA, USA), and a PCR from skin crust obtained from the site of the tick bite yielded a negative result. As infection with $F$. tularensis was suspected, whole blood and the skin crust were subjected to PCR testing. A real-time PCR kit (NZYTech, Lisboa, Portugal) targeting the succinate dehygdrogenase (sdhA) gene was used. The DNA isolate from the skin specimen yielded a positive result, while the blood was negative. To further characterize the subspecies, multilocus sequence typing (MLST) was attempted as previously described [4]. This MLST scheme employs seven genes. Only three out of these seven genes (tpiA, trpE and uup) yielded a specific result after sequencing and were submitted to GenBank (Acc. No. MZ031935-MZ031937). When comparing the obtained sequences to the NCBI database by BLAST search (https:/ / blast.ncbi.nlm.nih.gov/Blast.cgi, accessed on 1 March 2021), we identified the skin sample as containing F. tularensis subsp. holarctica. The final treatment with ciprofloxacin $500 \mathrm{mg}$ b.i.d. for 10 days was highly effective, and a rapid resolution of symptoms was achieved. Written consent to publish the report was obtained from the mother of the patient.

\section{Conclusions}

In Europe, F. tularensis subsp. holarctica is the only agent of tularemia among the four other known subspecies of the zoonotic bacterium recognized worldwide [5]. Given the low seroprevalence to $F$. tularensis of $0.5 \%$ in healthy individuals [6] and sporadic cases reported each year $[7,8]$, the infections may be considered rare in Austria. Based on the registry of 
the Federal Ministry of Labour, Social Affairs, Health and Consumer Protection [7], the mean number of cases per year reported from 2015 to 2019 was 11 (range 4-20 cases per year). Most cases were reported in Lower Austria, Upper Austria and Tyrol. With regard to transmission by ticks, such infections occur rarely in relation to other tick-borne infections, which we recently demonstrated in a study assessing the risk for tick-borne diseases after a tick bite [9]. Among 482 participants bitten by 1295 ticks, no patients with symptoms suggestive of tularemia were observed. A small case series of tick-borne tularemia was recently reported in Western Austria [10]. The diagnosis was made by serological testing and by molecular identification of the pathogen in a lymph node. From a practical point of view, the invasive character of such a procedure is a critical limitation to PCR testing in the outpatient area and in children. Application of skin swabs from the ulcer to identify F. tularensis by PCR was reported during an outbreak of ulceroglandular tularemia in Sweden [11]. Obviously, a skin crust from the ulcer is also an adequate specimen for this purpose, which we demonstrate with our case. Culture of $F$. tularensis is a possible alternative for a direct identification of the pathogen, but it can be only carried out in a BSL-3 laboratory because of the high virulence of the pathogen. Moreover, the sensitivity of PCR was shown to be superior compared to the culture [12].

Serologic testing was helpful to make the diagnosis of the infection in our patient (Table 1). The agglutination assay and the IgG and IgM ELISA were positive nearly three weeks after the infection. The highest levels of antibodies were observed two months after the infection, and they were still positive 10 months thereafter (Table 1). These findings are in line with a recent validation study showing a 100\% sensitivity of the ELISA used in our laboratory three weeks after onset of symptoms [13]. We also found elevated antibodies to Bartonella henselae in an indirect immunofluorescence assay, likely reflecting an old infection, and an increase of IgM to Borrelia burgdorferi sensu lato in a follow-up sample, although without symptoms typical for Lyme borreliosis.

Due to a lack of DNA extract, we were not able to repeat the investigation of missing genes, and therefore we could not provide a full MLST analysis of our isolate that would have allowed us to draw further phylogeographical and phylogenetic conclusions. However, the three allele sequences of the MLST scheme obtained during this investigation are useful for future analysis, and we therefore made them publicly available through GenBank in the NCBI database. The analysis to the species level is consistent with the reported epidemiology of F. tularensis, as F. tularensis subsp. holartica is the only species responsible for human infection in Europe. Thus far, molecular data on F. tularensis isolates in Austria are scarce. An analysis of 9 F. tularensis subsp. holartica isolates [14] by Gyuranecz et al. assigned these isolates to group B.13, which is prevalent in central and eastern European countries [15].

F. tularensis is an emerging pathogen in Europe, and prevention of infections is difficult because of the wide range of infection sources and routes of transmission. In the case of ulceroglandular manifestations, rapid diagnosis is recommended by molecular testing of skin specimens, which allows obviating invasive procedures such as biopsies or the surgical removal of lymph nodes.

Author Contributions: Conceptualization, M.M.; methodology, M.M., A.-M.S., F.P. and C.M.; investigation, A.-M.S., F.P. and C.M.; resources, M.M. and A.-M.S.; data curation, M.M. and A.-M.S.; writing-original draft preparation, M.M. and A.-M.S.; writing-review and editing, A.-M.S., G.S., J.R. and H.S.; visualization, A.-M.S. and C.M.; supervision H.S., G.S. and J.R.; project administration, M.M.; funding acquisition, H.S. All authors have read and agreed to the published version of the manuscript.

Funding: This research received no external funding.

Institutional Review Board Statement: Ethical review and approval were waived for this study, because the sole purpose of the examinations and the treatment was to provide a health benefit to the patient. 
Informed Consent Statement: Written informed consent to publish this paper has been obtained from the mother of the patient.

Data Availability Statement: Not applicable.

Conflicts of Interest: M.M. is an unpaid member of the Executive Committee of ESGBOR, the ESCMID Study Group on Lyme Borreliosis. M.M. discloses serving as a consultant for Pfizer unrelated to this study. Other authors declare no conflict of interest.

\section{References}

1. Maurin, M.; Gyuranecz, M. Tularaemia: Clinical aspects in Europe. Lancet Infect. Dis. 2016, 16, 113-124. [CrossRef]

2. Seiwald, S.; Simeon, A.; Hofer, E.; Weiss, G.; Bellmann-Weiler, R. Tularemia Goes West: Epidemiology of an Emerging Infection in Austria. Microorganisms 2020, 16, 1597. [CrossRef] [PubMed]

3. Austrian Agency of Food and Health Safety. Available online: https://www.ages.at/themen/krankheitserreger/tularaemiehasenpest/ (accessed on 18 June 2021).

4. Svensson, K.; Larsson, P.; Johansson, D.; Byström, M.; Forsman, M.; Johansson, A. Evolution of subspecies of Francisella tularensis. J. Bacteriol. 2005, 187, 3903-3908. [CrossRef] [PubMed]

5. Sjöstedt, A.B. Francisella. Proteobacteria. In Bergey's Manual of Systematic Bacteriology, 2nd ed.; Part B; Brenner, D.J., Stanley, J.T., Garrity, G.M., Eds.; Springer: New York, NY, USA, 2005; Volume 2, pp. 200-210.

6. Tobudic, S.; Nedomansky, K.; Poeppl, W.; Müller, M.; Faas, A.; Mooseder, G.; Allerberger, F.; Stanek, G.; Burgmann, H. Seroprevalence for Coxiella burnetii, Francisella tularensis, Brucella abortus and Brucella melitensis in Austrian adults: A crosssectional survey among military personnel and civilians. Ticks Tick Borne Dis. 2014, 5, 315-317. [CrossRef] [PubMed]

7. Federal Ministry of Labour, Social Affairs, Health and Consumer Protection. Jahresstatistik Meldepflichtiger Infektionskrankheiten 1990-2019. Available online: https:/ / www.sozialministerium.at/Themen/Gesundheit/ (accessed on 1 June 2021).

8. Antonitsch, L.; Weidinger, G.; Stanek, G.; Markowicz, M. Francisella tularensis as the cause of protracted fever. BMC Infect. Dis. 2020, 20, 327. [CrossRef] [PubMed]

9. Markowicz, M.; Schötta, A.-M.; Höss, D.; Kundi, M.; Schray, C.; Stockinger, H.; Stanek, G. Infections with Tickborne Pathogens after Tick Bite, Austria, 2015-2018. Emerg. Infect. Dis. 2021, 27, 1048-1056. [CrossRef]

10. Schroll, A.; Theurl, I.; Georgi, E.; Zange, S.; Rettenbacher, T.; Bellmann-Weiler, R.; Weiss, G. Newly emerging ulceroglandular tularaemia in Western Austria. Ticks Tick Borne Dis. 2018, 9, 1331-1333. [CrossRef] [PubMed]

11. Johansson, A.; Berglund, L.; Eriksson, U.; Göransson, I.; Wollin, R.; Forsman, M.; Tärnvik, A.; Sjöstedt, A. Comparative analysis of PCR versus culture for diagnosis of ulceroglandular tularemia. J. Clin. Microbiol. 2000, 38, 22-26. [CrossRef] [PubMed]

12. Sjöstedt, A.; Eriksson, U.; Berglund, L.; Tärnvik, A. Detection of Francisella tularensis in ulcers of patients with tularemia by PCR. J. Clin. Microbiol. 1997, 35, 1045-1048. [CrossRef] [PubMed]

13. Yanes, H.; Hennebique, A.; Pelloux, I.; Boisset, S.; Bicout, D.J.; Caspar, Y.; Maurin, M. Evaluation of In-House and Commercial Serological Tests for Diagnosis of Human Tularemia. J. Clin. Microbiol. 2017, 56, e01440-17. [CrossRef] [PubMed]

14. Gyuranecz, M.; Birdsell, D.N.; Splettstoesser, W.; Seibold, E.; Beckstrom-Sternberg, S.M.; Makrai, L.; Fodor, L.; Fabbi, M.; Vicari, N.; Johansson, A.; et al. Phylogeography of Francisella tularensis subsp. holarctica, Europe. Emerg. Infect. Dis. 2012, 18, $290-293$. [CrossRef] [PubMed]

15. Kevin, M.; Girault, G.; Caspar, Y.; Cherfa, M.A.; Mendy, C.; Tomaso, H.; Gavier-Widen, D.; Escudero, R.; Maurin, M.; Durand, B.; et al. Phylogeography and Genetic Diversity of Francisella tularensis subsp. holarctica in France (1947-2018). Front. Microbiol. 2020, 11, 287. [CrossRef] [PubMed] 